\title{
2-Amino-nonyl-6-methoxyl-tetralin muriate inhibits sterol C-14 reductase in the ergosterol biosynthetic pathway
}

Rong-mei LIANG ${ }^{1,2}$, Yong-bing CAO ${ }^{1, *}$, Kai-hua FAN ${ }^{2}, Y_{i} X^{1}{ }^{1}$, Ping-hui GAO ${ }^{1}$, You-jun ZHOU ${ }^{3}$, Bao-di DAl ${ }^{4}$, Yong-hong TAN², Shi-hua WANG ${ }^{2}$, Hui TANG ${ }^{3}$, Hong-tao LIU $^{5}$, Yuan-ying JIANG ${ }^{1, *}$

${ }^{1}$ Department of Pharmacology, School of Pharmacy, Second Military Medical University, Shanghai 200433, China; ${ }^{2}$ Department of Pharmacy, General Hospital of Chengdu Military Command Region, Chengdu 610083, China; ${ }^{3}$ Department of Medicinal Chemistry, School of Pharmacy, Second Military Medical University, Shanghai 200433, China; ${ }^{4}$ Department of Pharmacology, School of Life Science and Biopharmacology, Shenyang Pharmaceutical University, Shenyang 110016, China; ${ }^{5}$ Department of Pharmacy,Beijing Stomatological Hospital,Capital Medical University, Beijing 100050, China

Aim: To investigate the action mechanism of a novel chemical structural aminotetralin derivate, 2-Amino-Nonyl-6-Methoxyl-Tetralin Muriate (10b), against Candida albicans ( $C$ albicans) in the ergosterol biosynthetic pathway.

Methods: Antifungal susceptibility test of $10 \mathrm{~b}$ was carried out using broth microdilution method, the action mechanism of 10b against C albicans was investigated by GC-MS spectrometry and real-time RT-PCR assay, and cytotoxicity of 10b in vitro was assessed by MTS/ PMS reduction assay.

Results: $10 \mathrm{~b}$ reduced the ergosterol content markedly, and the $50 \%$ ergosterol content inhibitory concentration (ECIC 50 value) was 0.08 $\mu \mathrm{g} / \mathrm{mL}$. Although the sterol composition of 10b-grown cells was completely identical with that of erg24 strain, the content of ergosta8,14,22-trienol in 10b-grown cells was much higher than that in erg24 strain. Real-time RT-PCR assay revealed a global upregulation of sterol metabolism genes. In addition, the $50 \%$ inhibitory concentration $\left(\mathrm{IC}_{50}\right.$ value $)$ of $10 \mathrm{~b}$ was $11.30 \mathrm{\mu g} / \mathrm{mL}$ for murine embryonic fibroblasts and $35.70 \mu \mathrm{g} / \mathrm{mL}$ for human normal liver cells.

Conclusion: 10b possessed a mode of action different from that of azoles and morpholines, whose targets were sterol C-14 reductase (encoded by ERG24 gene) and sterol C-5 desaturase (encoded by ERG3) related enzyme. Although 10b seemed to reduce MTS/PMS reduction in a dose dependent manner, $\mathrm{IC}_{50}$ value for mammalian cells was much higher than $50 \%$ minimum inhibitory concentration $\left(\mathrm{MIC}_{50}\right)$ value for $\mathrm{C}$ albicans. This indicates that the formulation is preliminarily safe and warrants further study for possible human applications.

Keywords: Candida albicans; sterol C-14 reducase; ergosterol; 2-amino-nonyl-6-methoxyl-tetralin muriate

Acta Pharmacologica Sinica (2009) 30: 1709-1716; doi: 10.1038/aps.2009.157; published online 16 Nov 2009

\section{Introduction}

Current therapy for invasive mycoses uses a relatively reduced number of antifungal drugs such as polyenes, azoles and echinocandins. The polyene antibiotic amphotericin B $(\mathrm{AMB})$ remains to be the "gold standard" for the treatment of severe mycoses, but its severe acute and chronic toxicities such renal function impairment limit its clinical use ${ }^{[1,2]}$. Azoles are the most common agents for the treatment of Candida infections owing to their fungistatic and inhibitorty effects on cytochrome P450 enzyme lanosterol demethylase (encoded

* To whom correspondence should be addressed.

E-mail ybcao@vip.sina.com and jiangyysmmu@163.com

Received 2009-08-11 Accepted 2009-09-23 by ERG11 gene), a key enzyme in ergosterol biosynthesis. Of them, fluconazole (FLC) and itraconazole (ITZ) are the drugs of choice for the treatment of severe systemic mycoses. Ketoconazole $(\mathrm{KCZ})$ is widely used in the treatment of superficial mycoses. Nevertheless, azole resistance and cross-resistance have been documented in clinical Candida species ${ }^{[3,4]}$. Despite continuous expansion in the arsenal of antifungal drugs, antifungal drugs available cannot meet the increasing requirements for managing infections in medically complex patients.

The potential loss of efficacy of azoles has prompted concerted efforts to discover new drugs that might block fungal growth at different metabolic sites ${ }^{[5]}$. Additional steps in ergosterol biosynthesis may be effective targets to be explored in this search. The reaction catalyzed by sterol C-14 reductase 
may be a good target for an antifungal suitable for human use. sterol C-14 reductase ends C-14 modification reactions initiated by cytochrome P-450 lanosterol 14alpha-demethylase. An antifungal attack at this target by morpholines such as fenpropimorph (Fm) and amorolfine in Saccharomyces cerevisiae resulted in accumulation of ignosterol (ergosta-8,14-dienol), thus perturbing yeast membrane function and inhibiting the uptake of glucose and pyridines ${ }^{[6]}$. Morpholines have been proved to be effective against fungal plant pathogens ${ }^{[7]}$, of which amorolfine has been successfully applied to the treatment of human tinea pedis, onychomycosis and other foot mycoses owing to its potent fungistatic and fungicidal activity in vitro against clinical isolates ${ }^{[8-10]}$.

2-Aminotetralin derivatives were synthesized as novel chemical structural antifungal agents by virtue of their high antifungal activity, broad antifungal spectra and potentially low toxicity ${ }^{[11]}$. Of them, 10b (Figure 1) was found to have the strongest antifungal activity in vitro, especially against FLCresistant $C$ albicans strains. The aim of the present work was to further investigate the mechanism of $10 \mathrm{~b}$ action against $C$ albicans in the ergosterol biosynthetic pathway.

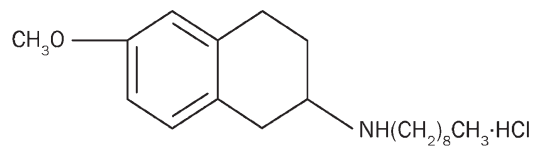

Figure 1. Chemical structure of 2-amino-nonyl-6-methoxyl-tetralin muriate (10b).

\section{Materials and methods}

\section{Antifungal agents}

Antifunal reagents used in the present experiment included FLC solution (Pfizer, Inc, New York, NY, USA); ITZ and KCZ (Sigma, St Louis, MO, USA); Fm (Dr Ehrenstorfer, Inc, Augsburg, Germany); 10b (Department of Medicinal chemistry, School of Pharmacy, Shanghai, China); stock solutions of various concentrations in dimethyl sulfoxide (DMSO) (Sigma); and cell proliferation kit (MTS/PMS) (Promega Co, Madison, USA).

\section{Organisms}

Except for BWP17, NJ51-2, SC5314, and SC5314R, 24 C albicans strains were from the Dermatology Department of the First Hospital of Beijing University (Beijing, China). C albicans SC5314 was kindly provided by Dr William A FONZI from the Department of Microbiology and Immunology Georgetown University (Washington, USA). SC5314R was induced from SC5314 by FLC in our laboratory. C albicans strain BWP17

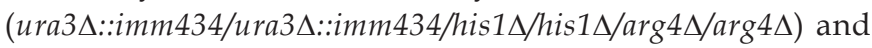
NJ51-2 (erg24/erg24) were kindly provided by Dr Joseph HEITMAN from the Department of Molecular Genetics and Microbiology, Duke University Medical Center (Durham, NC, USA). NJ51-2 was derived from BWP17 with C albicans ERG24 gene disrupted $^{[12]}$. The two strains (BWP17 and NJ51-2) were used for GC-MS assay. Uridine $(80 \mu \mathrm{g} / \mathrm{mL})$ was added to ensure the growth of BWP17.

All strains were cultivated at $30^{\circ} \mathrm{C}$ under constant shaking $(200 \mathrm{r} / \mathrm{min}$ ) in a liquid complete medium (YPD) consisting of $1 \%(w / v)$ yeast extract, $2 \%(w / v)$ peptone and $2 \%(w / v)$ dextrose. The synthetic dextrose medium containing $0.67 \%(w / v)$ yeast nitrogen base without amino acids and $2 \%(w / v)$ dextrose was buffered with $0.165 \mathrm{~mol} / \mathrm{L}$ morpholinepropanesulfonic acid (MOPS; Sigma), with $\mathrm{pH}$ adjusted to 7.0 with $\mathrm{NaOH}$.

BALB/C 3T3 murine embryo fibroblast and L-02 (HL-7702) human normal liver cells were obtained from the Chinese Academy of Sciences Cell Bank (Shanghai, China). All tissue culture plastics were purchased from TPP (Switzerland). 3T3 cells were routinely grown in the medium (Dulbecco's modified Eagle's medium (DMEM) supplemented with L-glutamine $(4 \mathrm{mmol} / \mathrm{L})$, penicillin $(100 \mathrm{U} / \mathrm{mL})$, streptomycin $(100$ $\mu \mathrm{g} / \mathrm{mL}$ ) and $10 \%(v / v)$ calf bovine serum (CBS). L-02 human normal liver cells were routinely grown in the medium (RPMI 1640 supplemented with $L$-glutamine $(4 \mathrm{mmol} / \mathrm{L})$, penicillin $(100 \mathrm{U} / \mathrm{mL})$, streptomycin $(100 \mu \mathrm{g} / \mathrm{mL})$ and $20 \%(v / v)$ CBS. The cultures were maintained in a $37^{\circ} \mathrm{C}$ incubator in a humidified atmosphere of 95: 5 air: $\mathrm{CO}_{2}$. The cells were grown to confluency in $75-\mathrm{cm}^{2}$ flasks, incubated at $37^{\circ} \mathrm{C}$ with trypsin/ EDTA solution for 2-5 min, pipetted to 96 -well plates at the desired density $(100 \mu \mathrm{L})$, and allowed to attach for $24 \mathrm{~h}$ prior to exposure to $10 \mathrm{~b}$.

\section{Antifungal susceptibility test}

Drug sensitivities were assayed by microbroth dilution in 96-well plates according to methods of the Clinical and Laboratory Standards Institute (CLSI, formerly NCCLS) $(\mathrm{M} 27-\mathrm{A} 2)^{[13]}$. Briefly, cells were inoculated into successive wells of a 96-well microtiter plate containing serial two-fold dilutions of antifungal drugs in RPMI-1640 medium buffered to $\mathrm{pH} 7.0$ with MOPS. The initial concentration of the fungal suspension in RPMI-1640 medium was $1 \times 10^{3}$ colony forming unit $(\mathrm{CFU}) / \mathrm{mL}$. After incubation at $30^{\circ} \mathrm{C}$ for $24 \mathrm{~h}$, absorbance at $630 \mathrm{~nm}$ was determined in an ELISA reader (Multiskan MK3). According to CLSI, we adopted Candida parapsilosis strain ATCC18062 as the quality control strain. The $\mathrm{MIC}_{80}$ result that falls within the requested limits is $0.25-1.0 \mu \mathrm{g} / \mathrm{mL}$ for fluconazole. Each isolate was tested in triplicate. Drug concentrations inhibiting growth to $50 \%$ and $80 \%$ of control levels $\left(\mathrm{MIC}_{50}\right.$ and $\mathrm{MIC}_{80}$ ) were estimated by interpolation.

\section{Sterol extraction}

Cells were grown to the stationary phase in YPD liquid medium at $30^{\circ} \mathrm{C}$ under constant shaking $(200 \mathrm{r} / \mathrm{min})$. Total sterols were extracted from whole cells based on the previous report ${ }^{[14]}$ with slight modifications. Briefly, Candida cells grown at $30^{\circ} \mathrm{C}$ to $0.2 O D_{600}$ unit $/ \mathrm{mL}$ were treated with or without antifungal agents, and incubated for $16 \mathrm{~h}$. Cells were then harvested by centrifugation at $3000 \times g$ at $4{ }^{\circ} \mathrm{C}$ for $5 \mathrm{~min}$ and washed three times with phosphate buffer saline (PBS). The net weight of the cell pellet (approximate $0.5 \mathrm{~g}$ )

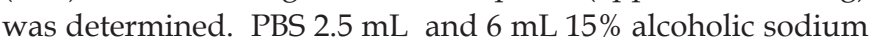


hydroxide solution $(15 \mathrm{~g} \mathrm{NaOH}$ and $10 \mathrm{~mL}$ sterile distilled water, brought to $100 \mathrm{~mL}$ with $100 \%$ ethanol) were added to each pellet and mixed by vortex for $1 \mathrm{~min}$. Cell suspensions were then incubated in an $80^{\circ} \mathrm{C}$ water bath for $1 \mathrm{~h}$. Following incubation, tubes were allowed to cool to room temperature. Total sterols were then extracted (three times) with $6 \mathrm{~mL}$ petroleum ether. Upper phases were combined and transferred to a clean borosilicate glass screw-cap tube. Sterile distilled water $6 \mathrm{~mL}$ was added to each tube and swirled for $1 \mathrm{~min}$. With water removed, the tubes were incubated in a $60{ }^{\circ} \mathrm{C}$ water bath until the petroleum ether layer volatilized completely. The resulting samples were stored at $-20{ }^{\circ} \mathrm{C}$ for use after they were dissolved by $0.5 \mathrm{~mL}$ hexamethylene.

GC-MS spectrometry analyses of sterols were done with a Thermo Focus DSQ gas chromatograph interfaced to a FactorFour VF-5MS Mass Spectrometer. GC separation was performed on a fused silica column (VF-5MS; $30 \mathrm{~m}$ by $0.25 \mathrm{~mm}$ by $0.25 \mu \mathrm{m}$ [film thickness]; Varian Inc). The injector temperature was $250^{\circ} \mathrm{C}$. The oven temperature was programmed to constant $100^{\circ} \mathrm{C}$ for $1 \mathrm{~min}$, followed by a temperature increase of $10{ }^{\circ} \mathrm{C} / \mathrm{min}$ to a final temperature of $300^{\circ} \mathrm{C}$. The final temperature was maintained for $10 \mathrm{~min}$. Helium was used as the carrier gas. The linear velocity was $1 \mathrm{ml} / \mathrm{min}$ with a split ratio 10:1. The mass spectrometer was in the electron impact ionization mode at $70 \mathrm{eV}$ electron energy. The ion source temperature was $250{ }^{\circ} \mathrm{C}$. Scanning was done from 41 to 460 atomic mass units at 0.6 -s intervals. The concentration of $10 \mathrm{~b}$ showing $50 \%$ reduction in ergosterol content $\left(\mathrm{ECIC}_{50}\right.$ value) was then calculated.

\section{Quantitative real-time RT-PCR assay}

Total RNA was extracted from C albicans SC5314 in synthetic dextrose medium using Fungal RNAout kit (TIANDS, china). Reverse transcription was performed in a total volume of $20 \mu \mathrm{L}$ with Avian Myeloblastosis Virus Reverse Transcripase (TaKaRa), Random Primer (6-mer) (TaKaRa) and $1 \mu \mathrm{g}$ total RNA, followed by the condition of $30^{\circ} \mathrm{C}$ for $10 \mathrm{~min}, 45^{\circ} \mathrm{C}$ for $15 \mathrm{~min}$, and $99^{\circ} \mathrm{C}$ for $2 \mathrm{~min}$, as recommended by the manufacturer. Real-time PCR reactions were performed with SYBR Green I (TaKaRa), using LightCycler Real-Time PCR system (Roche Molecular Biochemical). Gene-specific primers were designed using Discovery Studio Gene software (Accelrys, Inc). The thermal cycling conditions comprised an initial step at $95{ }^{\circ} \mathrm{C}$ for $10 \mathrm{~s}$, followed by 40 cycles at $95^{\circ} \mathrm{C}$ for $10 \mathrm{~s}, 62^{\circ} \mathrm{C}$ for $20 \mathrm{~s}$, and $72{ }^{\circ} \mathrm{C}$ for $15 \mathrm{~s}$. Change in SYBR Green I fluorescence in every cycle was monitored by the system software, and the threshold cycle $\left(C_{\mathrm{T}}\right)$ was measured. Using $18 \mathrm{~S}$ rRNA as the internal control, gene expression of SC5314 strain treated by 10b relative to SC5314 strain without treatment was calculated using the formula $2^{-\Delta \Delta C_{T}}$, where $\Delta C_{T}$ was the $C_{T}$ value of genes of interest minus that of the internal control, and $\Delta \Delta C_{T}$ was the mean $\Delta \mathrm{C}_{\mathrm{T}}$ value of SC5314 strain treated by $10 \mathrm{~b}$ minus that of SC5314 strain without treatment. Primer sequences used in real-time RT-PCR assay are listed in Table 1.
Table 1. List of primers used for real-time RT-PCR.

\begin{tabular}{|c|c|c|}
\hline Target gene & Primer pairs $\left(5^{\prime}-3^{\prime}\right)^{a}$ & $\begin{array}{l}\text { Amplicon } \\
\text { size (bp) }\end{array}$ \\
\hline \multirow[t]{2}{*}{$18 \mathrm{~s}$} & (F) TCTTTCTTGATTTTGTGGGTGG & 150 \\
\hline & (R) TCGATAGTCCCTCTAAGAAGTG & \\
\hline \multirow[t]{2}{*}{ ERG1 } & (F) TTAGAATCATGCCAAACC & 127 \\
\hline & (R) CCAАСТGTCATACCACCC & \\
\hline \multirow[t]{2}{*}{ ERG2 } & (F) TAATAATGCTGGTGGTGC & 167 \\
\hline & (R) CAGGATAAGCTGCTCTTT & \\
\hline \multirow[t]{2}{*}{ ERG3 } & (F) GTCTAATGACCCAGTTGT & 162 \\
\hline & R) TCTTCTTCTGCCTTTGCA & \\
\hline \multirow[t]{2}{*}{ ERG4 } & (F) TATACGCCAATGCTTGTG & 120 \\
\hline & (R) AGTAACTGAATGGAACCC & \\
\hline \multirow[t]{2}{*}{ ERG5 } & (F) AGATACCGTCCACCAGTC & 119 \\
\hline & (R) TGCAAAGCAGGATACAAT & \\
\hline \multirow[t]{2}{*}{ ERG6 } & (F) GCTACCGTTCATGCTCCA & 164 \\
\hline & (R) CCATCACCGACTTCAATA & \\
\hline \multirow[t]{2}{*}{ ERG7 } & (F) GCTTGGGCTTTGATAGGG & 106 \\
\hline & (R) TCCACTCACCAGTCGGTA & \\
\hline \multirow[t]{2}{*}{ ERG10 } & (F) TGCCTTGGGTCATCCTCT & 108 \\
\hline & (R) CCGTTACAAACACCAGCA & \\
\hline \multirow[t]{2}{*}{ ERG11 } & (F) GAATCCCTGAAACCAAT & 131 \\
\hline & (R) AGCAGCAGTATCCCATC & \\
\hline \multirow[t]{2}{*}{ ERG13 } & (F) TGGAACACGCTTACGATT & 191 \\
\hline & (R) CACATGGAAGGCACTGAA & \\
\hline \multirow[t]{2}{*}{ ERG24 } & (F) GGTGACTTAGCGTGGGT & 143 \\
\hline & (R) GCTGAGCGGAAGATGTA & \\
\hline
\end{tabular}

${ }^{a} \mathrm{~F}$, forward; $\mathrm{R}$, reverse.

\section{Cell viability assay}

Cell viability was tested using MTS [3-(4,5-dimethylthiazol2-yl)-5-(3-carboxymethoxyphenyl)-2-(4-sulfophenyl)- $2 \mathrm{H}$ tetrazolium] assay based on the reduction of MTS tetrazolium to a formazan product by dehydrogenase enzymes found in metabolically active cells in the presence of PMS (phenazine methosulfate), an electron-coupling agent, which was quantitated using an ELISA reader. According to the manufacturer's instructions, MTS/PMS assay was performed with appropriate controls. Cells were seeded in 96-well microtitre plates (for BALB/C 3 T3 cells, $4 \times 10^{3}$ cells $/ 100 \mu \mathrm{L}$ growth medium/well; for L-02 cells, $1 \times 10^{4}$ cells $/ 100 \mu \mathrm{L}$ growth medium/well) followed by $24 \mathrm{~h}$ incubation. The desired concentrations of $10 \mathrm{~b}$ (dissolved in methanol) were added. After $24 \mathrm{~h}$, MTS/PMS reagent $(20 \mu \mathrm{L})$ was added in each well and incubated for $2 \mathrm{~h}$. $A_{492}$ was recorded using an ELISA reader (Multiskan MK3). The $10 \mathrm{~b}$ concentration showing $50 \%$ reduction in cell viability $\left(\mathrm{IC}_{50}\right.$ value) was then calculated.

\section{Statistics}

All the experiments were carried out in triplicate independently. The data obtained were expressed in terms of mean $\pm S D$. Wherever appropriate, the data were also subjected to unpaired two tailed Student's $t$-test. A value of $P<0.05$ was considered statistically significant. 
Table 2. In vitro antifungal activities of $10 \mathrm{~b}, \mathrm{FLC}, \mathrm{ITZ}$, and $\mathrm{KCZ}$ against $C$ albicans ${ }^{\mathrm{a}}$.

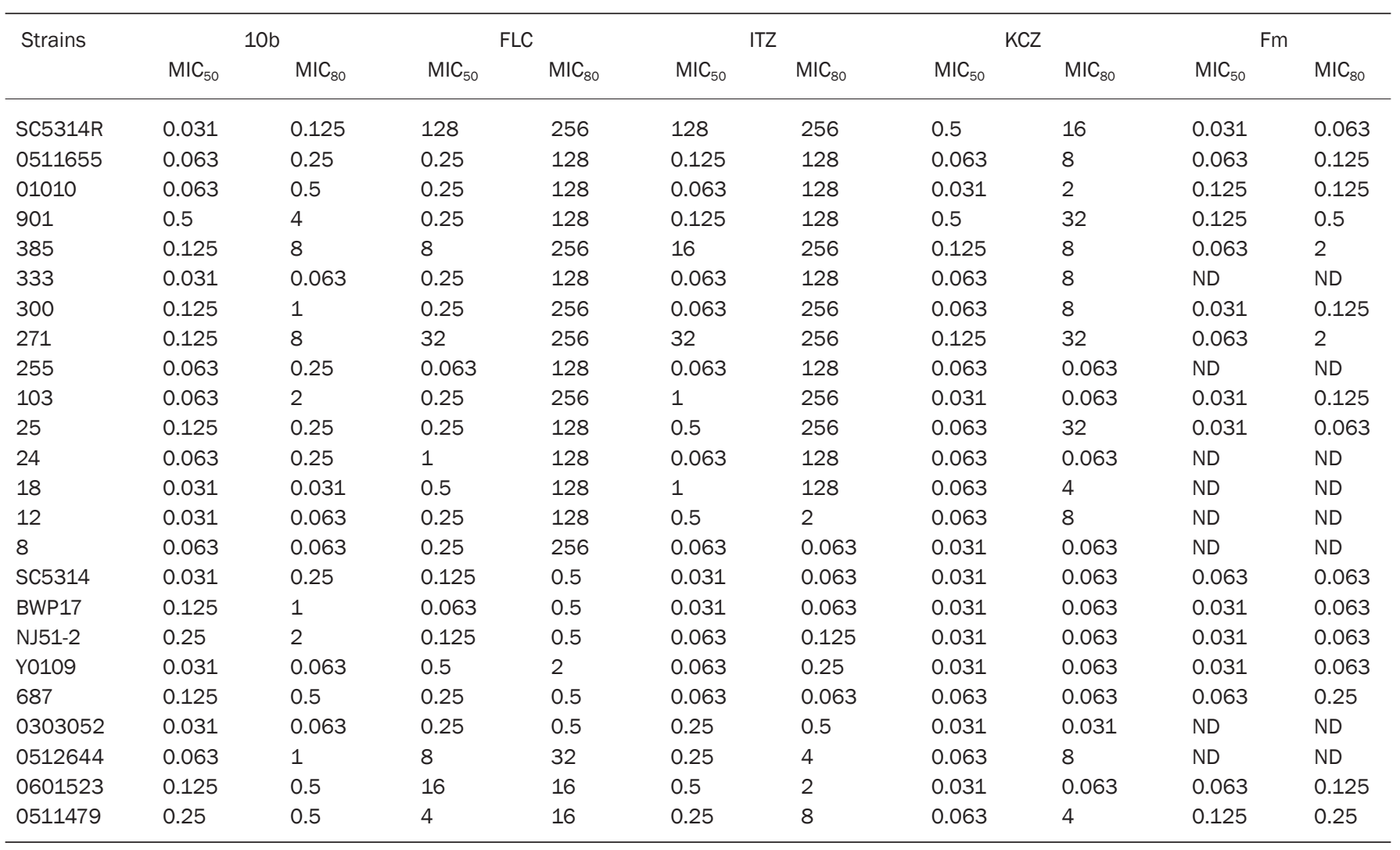

a) $\mu \mathrm{g} / \mathrm{mL}$; “ND”, not determined.

\section{Results}

\section{Antifungal activity in vitro}

As shown in Table 2, 10b possessed potent activities against almost all $\mathrm{C}$ albicans isolates, with $\mathrm{MIC}_{80}$ value ranging from 0.063 to $8 \mu \mathrm{g} / \mathrm{mL}$, which were similar to or more powerful than that of KCZ, and 4096 times lower than that of FLC. Despite high resistance to FLC and ITZ (both MIC $_{50}$ value 128 $\mu \mathrm{g} / \mathrm{mL}$ ) for isolate SC5314R, 10b, and Fm displayed powerful antifungal activity against this strain, $\mathrm{MIC}_{50}$ value being 0.031 $\mu \mathrm{g} / \mathrm{mL}$.

Sterol C-14 reductase might be the most important target of $10 \mathrm{~b}$ GC-MS analyses showed that $10 \mathrm{~b}$ reduced the content of ergostrol in a dose-dependent manner, where $\mathrm{ECIC}_{50}$ value was $0.08 \mu \mathrm{g} / \mathrm{mL}$ (Figure 2). Gas chromatography showed that KCZ-grown cells produced a profile with 24-methylenelanost-8-en-3-ol (73.55\%) as the predominant sterol (Table $3)$, while $10 \mathrm{~b}$-grown cells produced a profile similar to that of homozygous erg24 strain ${ }^{[12]}$, in which ergosta-8, 14-dienol (ignosterol) was a major sterol accompanied by large amounts of ergosta-8,14,22-trienol. To see whether $10 \mathrm{~b}$ affected sterol C-14 reductase, sterols were extracted from the wild-type strain (BWP17) and erg24 strain (NJ51-2) before and after treatment with $10 \mathrm{~b}$ and Fm. Table 3 shows that the sterols composition of 10b-grown cells was completely identical to that of erg24 strain except a different proportion in ergosta-8,14,22- trienol to ignosterol. The ratio was 0.63: 1 in 10b-grown wildtype strain and 0.89: 1 in 10b-grown erg24 strain. However, the ratio was 1: 6.82 in $\operatorname{erg} 24$ strain without treatment. The wild-type strain treated by Fm produced a profile with ignos-

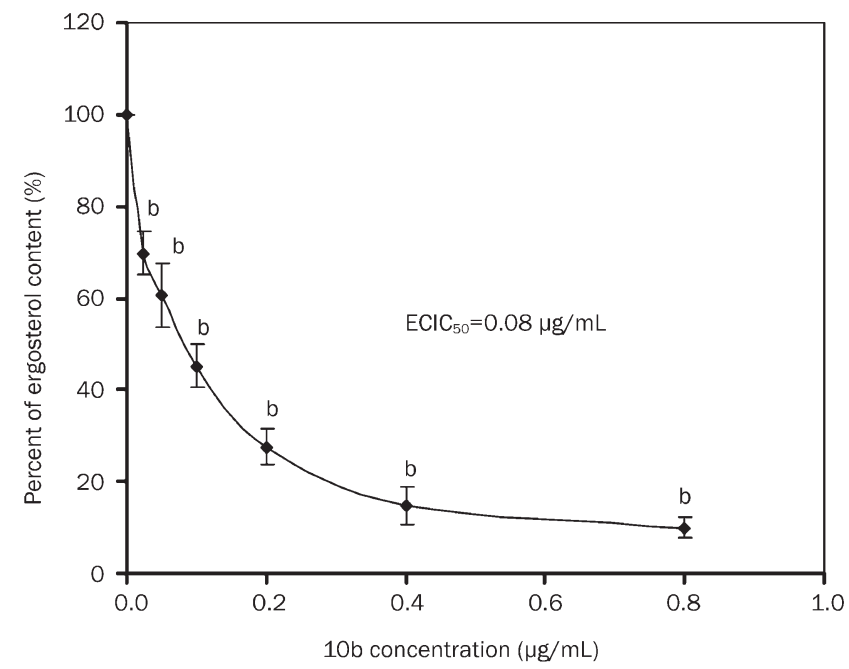

Figure 2. Percentage of the ergosterol content in $C$ albicans BWP17 strain treated with different concentrations of $10 \mathrm{~b}$. Ergosterol biosynthesis is expressed as the percentage of that of control cells (unexposed cells). ${ }^{\mathrm{b}} \mathrm{P}<0.05$ vs control. 
Table 3. Analyses of the sterol composition and relative abundance of sterols within wild-type (BWP17), erg24 (NJ51-2), 10b-grown cells and Fmgrown cells ${ }^{\mathrm{a}}$.

\begin{tabular}{|c|c|c|c|}
\hline Strains $^{a}$ & Sterol & $\begin{array}{l}\text { Percent } \\
\text { sterol }\end{array}$ & Mass \\
\hline \multirow{7}{*}{$\begin{array}{l}\text { BWP17 } \\
\text { (wild-type strain) }\end{array}$} & Squalene & 1.16 & 410 \\
\hline & Zymosterol & 3.46 & 384 \\
\hline & Ergosterol & 80.19 & 396 \\
\hline & Fecosterol & 8.71 & 398 \\
\hline & Lanosterol & 2.57 & 426 \\
\hline & 4,4-dimethyl zymosterol & 2.61 & 412 \\
\hline & Identification of sterols uncertain & 4.30 & \\
\hline \multirow{6}{*}{$\begin{array}{l}\text { BWP17 } \\
\text { (treated by KCZ) }\end{array}$} & Squalene & 0.65 & 410 \\
\hline & Ergosterol & 3.54 & 396 \\
\hline & 4,14-dimethyl-ergosta-8,24(28)-dienol & 10.28 & 426 \\
\hline & Lanosterol & 10.52 & 426 \\
\hline & 24-methylene-lanost-8-en-3-ol & 73.55 & 440 \\
\hline & Identification of sterols uncertain & 1.46 & \\
\hline \multirow{7}{*}{$\begin{array}{l}\text { BWP17 } \\
\text { (treated by 10b) }\end{array}$} & Squalene & 0.82 & 410 \\
\hline & Ergosta-5,8,14,22-tetraenol & 9.94 & 394 \\
\hline & Ergosterol & 23.91 & 396 \\
\hline & Ergosta-8,14,22-trienol3 & 22.35 & 396 \\
\hline & Ergosta-8,14-dinol(ignosterol) & 35.54 & 398 \\
\hline & 4,4-Dimethylcholesta-8,14,22-trien-ol & 3.01 & 410 \\
\hline & Identification of sterols uncertain & 4.43 & \\
\hline \multirow{7}{*}{$\begin{array}{l}\text { BWP17 } \\
\text { (treated by Fm) }\end{array}$} & Squalene & 2.27 & 410 \\
\hline & Ergosta-5,8,14,22-tetraenol & 5.11 & 394 \\
\hline & Ergosterol & 6.40 & 396 \\
\hline & Ergosta-8,14-dienol(ignosterol) & 68.30 & 398 \\
\hline & Ergosta-8-en-3-ol & 7.32 & 400 \\
\hline & 4,4-Dimethylcholesta-8,14,22-trien-ol & 2.88 & 410 \\
\hline & Identification of sterols uncertain & 7.72 & \\
\hline \multirow{6}{*}{$\begin{array}{l}\text { NJ51-2 } \\
\text { (erg24 strain) }\end{array}$} & Squalene & 1.24 & 410 \\
\hline & Ergosta-5,8,14,22-tetraenol & 5.52 & 394 \\
\hline & Ergosta-8,14,22-trienol & 10.46 & 396 \\
\hline & Ergosta-8,14-dinol(ignosterol) & 71.36 & 398 \\
\hline & 4,4-Dimethylcholesta-8,14,22-trien-ol & 6.40 & 410 \\
\hline & Identification of sterols uncertain & 5.02 & \\
\hline \multirow{6}{*}{$\begin{array}{l}\text { NJ51-2 } \\
\text { (treated by 10b) }\end{array}$} & Squalene & 0.84 & 410 \\
\hline & Ergosta-5,8,14,22-tetraenol & 2.60 & 394 \\
\hline & Ergosta-8,14,22-trienol & 40.79 & 396 \\
\hline & Ergosta-8,14-dienol(ignosterol) & 45.83 & 398 \\
\hline & 4,4-Dimethylcholesta-8,14,22-trien-ol & 6.49 & 410 \\
\hline & Identification of sterols uncertain & 3.45 & \\
\hline \multirow{6}{*}{$\begin{array}{l}\text { NJ51-2 } \\
\text { (treated by Fm) }\end{array}$} & Squalene & 0.58 & 410 \\
\hline & Ergosta-5,8,14,22-tetraenol & 2.59 & 394 \\
\hline & Ergosta-8,14,22-trienol & 9.90 & 396 \\
\hline & Ergosta-8,14-dienol(ignosterol) & 78.70 & 398 \\
\hline & 4,4-Dimethylcholesta-8,14,22-trien-ol & 4.44 & 410 \\
\hline & Identification of sterols uncertain & 3.79 & \\
\hline
\end{tabular}

\footnotetext{
${ }^{a}$ The concentrations of $\mathrm{KCZ}, 10 \mathrm{~b}$, and Fm are $3 \mu \mathrm{g} / \mathrm{mL}$.
}

terol as predominate sterol (68.3\%) accompanied with a new sterol, ergosta-8-en-3-ol (7.32\%) without a trace of ergosta8,14,22-trienol. Fm-grown erg 24 strain produced a profile completely identical to that of erg24 strain, whose ratio of ergosta-8,14,22-trienol to ignosterol was 1:7.95. In addition, a negative correlation was observed between $10 \mathrm{~b}$ concentrations and the ratios of ergosta-8,14,22-trienol to ignosterol (Table 4). The ratio of ergosta-8,14,22-trienol to ignosterol was from 7.63 to 0.76 when the concentration of $10 \mathrm{~b}$ increased from 0.025 to $0.8 \mu \mathrm{g} / \mathrm{mL}$.

Table 4. The content of ergosta-8,14,22-trienol and ignosterol as well as the ratio of ergosta-8,14,22-trienol to ignosterol in BWP17 strain treated with different concentrations of $10 \mathrm{~b}$.

\begin{tabular}{lcll}
\hline $\begin{array}{l}\text { Concentra- } \\
\text { tions of 10b } \\
\left(\mu g \cdot \mathrm{mL}^{-1}\right)\end{array}$ & $\begin{array}{c}\text { Content }(\mu \mathrm{g}) \\
\text { Ergosta-8,14,22- } \\
\text { trienol }\end{array}$ & Ignostrol & Ratio $^{\mathrm{a}}$ \\
\hline 0.025 & $156.23 \pm 15.71$ & $20.47 \pm 7.76$ & 7.63 \\
0.05 & $152.43 \pm 4.17$ & $50.65 \pm 7.70$ & 3.01 \\
0.1 & $95.36 \pm 13.06$ & $54.74 \pm 5.93$ & 1.74 \\
0.2 & $66.40 \pm 12.06$ & $53.67 \pm 10.69$ & 1.24 \\
0.4 & $73.92 \pm 6.95$ & $75.04 \pm 9.70$ & 0.99 \\
0.8 & $65.39 \pm 14.80$ & $85.77 \pm 14.63$ & 0.76 \\
\hline
\end{tabular}

${ }^{a}$ The ratio of Ergosta-8,14,22-trienol to Ignosterol.

\section{0b increases mRNA levels of sterol metabolism genes}

To study cellular responses to perturbation of ergosterol biosynthesis caused by $10 \mathrm{~b}$, real-time RT-PCR analysis was performed, and the results revealed a global upregulation of sterol metabolism genes in response to $10 \mathrm{~b}$ treatment. Figure 3 shows that the expression of gene ERG5, ERG10, and ERG7 significantly increased by $6.36,7.41$, and 6.05 fold respectively,

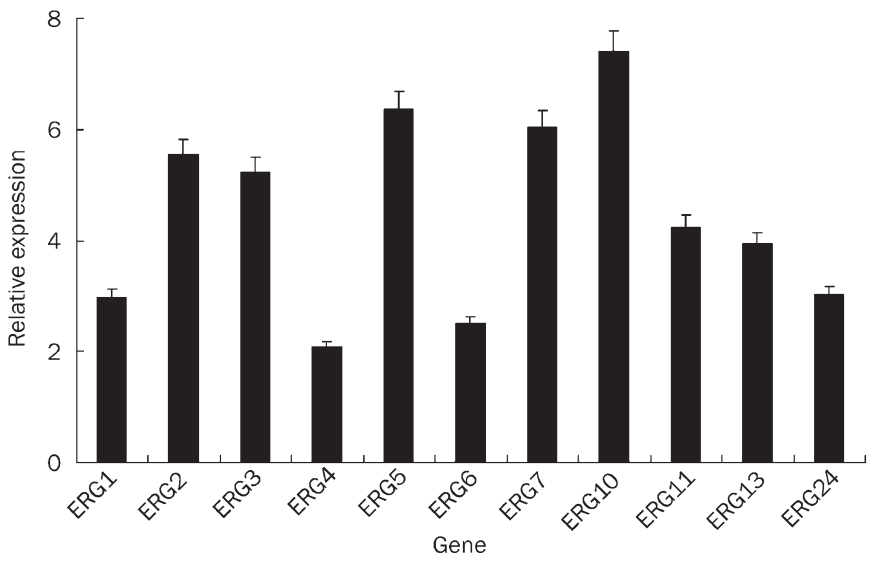

Figure 3. Gene expression changes of sterol metabolism genes in 10btreated SC5314 strain. The concentration of $10 \mathrm{~b}$ is $6 \mu \mathrm{g} / \mathrm{mL}$. All genes were examined by real-time RT-PCR with gene-specific primers. Relative fold change was calculated with $\mathrm{C}_{\mathrm{T}}$ value (see details in Materials and Methods). Mean \pm SD. $n=3$. 
and that gene ERG6, ERG1, ERG24, ERG13, ERG11, ERG3, and $E R G 2$ upregulated intermediately (2.5 fold to 5.54 fold).

\section{Dose-dependent toxicity of 10b on BALB/C 3 T3 and L-02 cells}

Based on investigation of the mechanism of $10 \mathrm{~b}$ against $C$ albicans, its cytotoxicity in vitro was further assessed using MTS/PMS reduction assay. Figure 4 shows that the cytotoxic response of BALB/C 3T3 and L-02 cells to $10 \mathrm{~b}$ appeared to be dose dependent, where $\mathrm{IC}_{50}$ value was $11.31 \mu \mathrm{g} / \mathrm{mL}$ and 35.70 $\mu \mathrm{g} / \mathrm{mL}$, respectively. In addition, no cytotoxic response was found in the two mammalian cells when the concentration of $10 \mathrm{~b}$ was $6 \mu \mathrm{g} / \mathrm{mL}$.
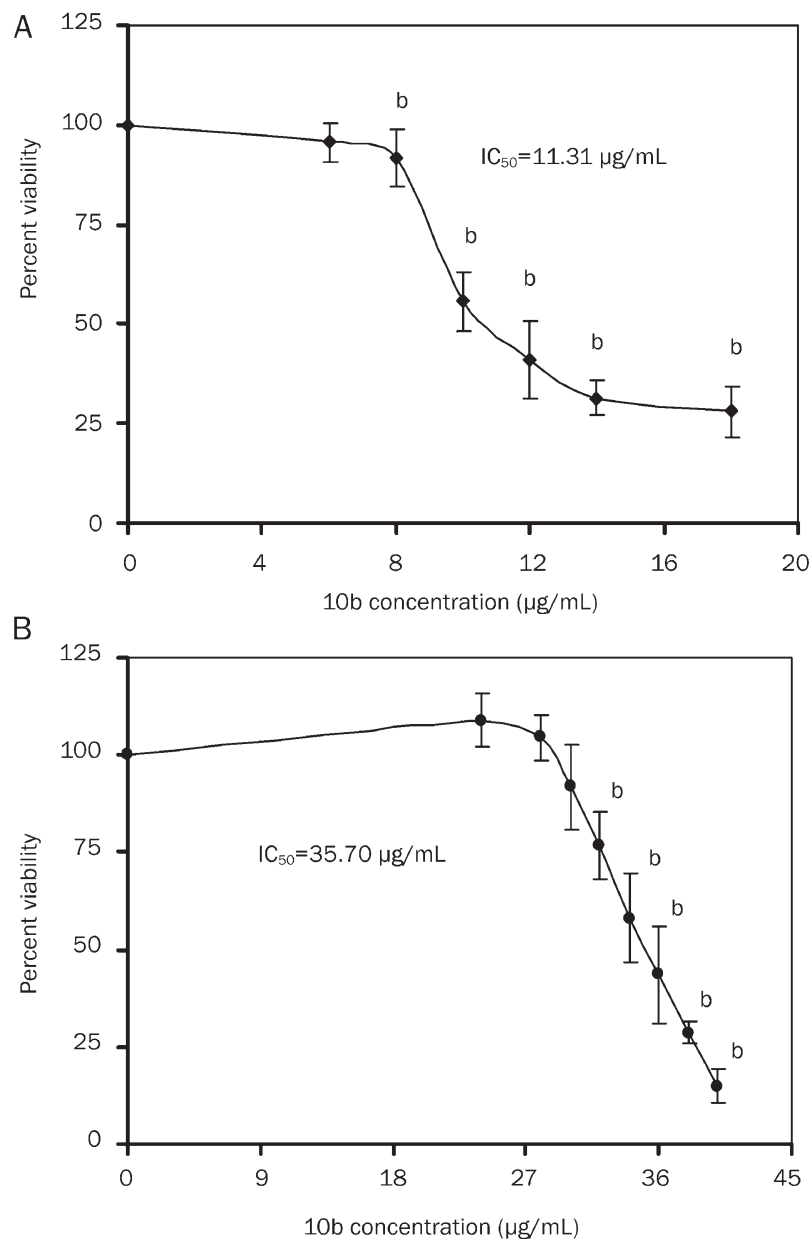

Figure 4. Percentage of viability measured by MTS/PMS assay in murine embryo fibroblast (A) and human liver cells (B) after treatment with $10 \mathrm{~b}$ for $24 \mathrm{~h}$. Mean \pm SD. $n=3$. An OD value of control cells (unexposed cells) was taken as $100 \%$ viability ( $0 \%$ cytotoxicity). ${ }^{b} P<0.05$ vs control.

\section{Discussion}

On the basis of the three-dimensional model of lanosterol 14ademethylase (CYP51) from C albicans constructed in previous studies ${ }^{[15-18]}$, a series of 2-aminotetralin compounds was designed and synthesized as antifungal agents. We hope that these compounds are able to interact with amino acid residues in the active site of CYP51 and avoid connection with the iron atom of heme, and therefore they can not only generate potent antifungal activity but attenuate severe toxicities of azoles. Experiments ${ }^{[11]}$ has confirmed that 2-aminotetralin derivatives possessed potential antifungal activities, especially against FLC-resistant $C$ albicans, Candida parapsilosis and Trichophyton rubrum. Theoretically, the most important action mechanism of 10b should inhibit CYP51 as other azoles do.

Unexpectedly, we found that $10 \mathrm{~b}$ had an action mode completely different from other azoles in the ergosterol biosynthetic pathway. Cells treated with $10 \mathrm{~b}$ produced a profile similar to that of homozygous erg24 strain, in which ignosterol and ergosta-8,14,22-trienol were major sterols and no trace of 24-methylene-lanost-8-en-3-ol was found. However, KCZgrown cells had a profile with 24-methylene-lanost-8-en-3-ol as the predominant sterol. We therefore postulate that sterol C-14 reductase, encoded by ERG24, instead of lanosterol 14ademethylase, encoded by ERG11, is an important target for 2-aminotetralin derivates in this pathway.

$10 \mathrm{~b}$ also showed an action mechanism different from that of morpholines in the ergosterol biosynthetic pathway, although both of them are sterol C-14 reductase inhibitors. Morpholines inhibit sterol C-8 isomerase, encoded by ERG2 gene, resulting in ergosta-8-en-3-ol accumulation. As sterol C-8 isomerase is situated in the downstream of sterol C-14 reductase, Fmgrown erg24 strain produced a profile completely identical to that of erg24 strain. Although the sterol composition of 10 b-grown cells was completely identical to that of erg24 strain, the ratio of ergosta-8,14,22-trienol to ignosterol was different. The content of ergosta-8,14,22-trienol in 10b-treated erg24 strain was much more than that in erg24 strain without $10 \mathrm{~b}$ treatment, indicating that there must be another important target upstream sterol C-14 reductase. We deduced that another target was an enzyme related to sterol C-5 desaturase, which catalyzes the conversion of ergosta-8,14,22-trienol to ergosta-5,8,14,22-tetraenol as presented in Figure 5. In addition, we found that the content of ignosterol built up in the wake of increase in the concentration of $10 \mathrm{~b}$, indicating that sterol C-5 desaturase related enzyme was the dominant target of $10 \mathrm{~b}$ at a low concentration, while the affinity of $10 \mathrm{~b}$ with sterol C-14 reducase augmented along with the increase in the concentration of $10 \mathrm{~b}$ and finally changed into the fundamental target at a higher concentration.

Ergosterol is an important constituent of cellular membranes and plays a fundamental role in many biological processes $^{[19-21]}$. 10b significantly reduced the ergostrol content by inhibiting the activity of sterol C-14 reducase and C-5 desaturase related enzyme, destructing the integration of the fungal membrane and finally leading to fungal death. To further investigate cellular responses to perturbation of ergosterol biosynthesis stimulated by $10 \mathrm{~b}$, we detected the expression of sterol metabolism genes by real-time RT-PCR analyses. The results revealed a global upregulation of sterol metabolism genes, including gene ERG24, ERG5, and ERG11, which is consistent with previous reports ${ }^{[22,23]}$. This was presumed as 


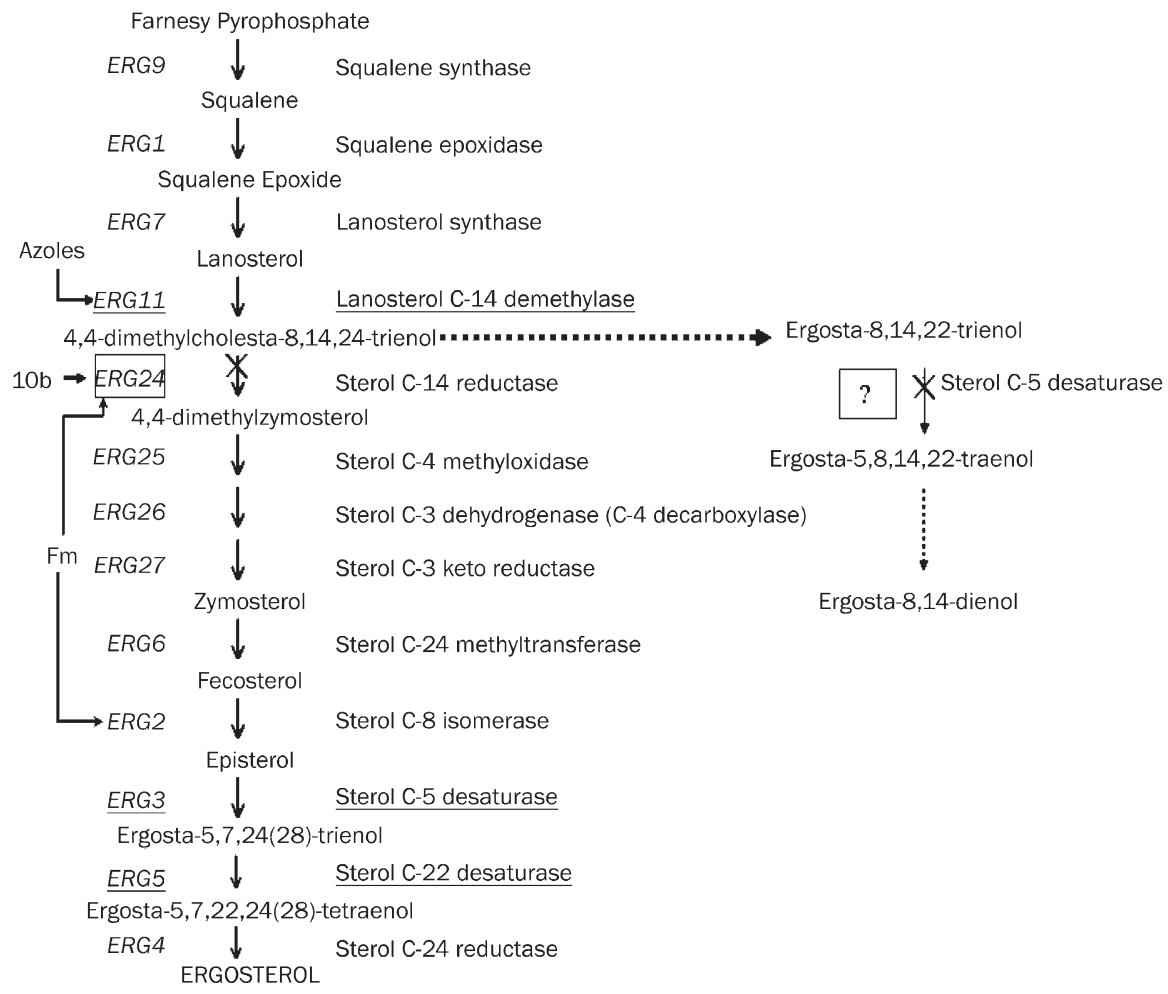

Figure 5. Proposed mechanism action of $10 \mathrm{~b}$ against $C$ albicans in the ergosterol biosynthetic pathway. a result of feedback control ${ }^{[24]}$. However, which mechanism is responsible for the global upregulation of sterol metabolism genes in response to ergosterol biosynthesis inhibitors remains unclear. One theory postulates that depletion of ergosterol or another sterol formed late in the pathway increases the expression of global sterol metabolism genes. Others argue that accumulation of an early substrate or toxic sterol by-products induces the expression of sterol metabolism genes. Upregulation of sterol metabolism genes in $10 \mathrm{~b}$ or azole-treated $C$ albicans suggests that change in transcript levels is not directly related to ergosterol biosynthesis in $C$ albicans.

The Interagency Coordinating Committee on the Validation of Alternative Methods (ICCVAM) recommends two standard cytotoxicity assays in order to better predict acute systemic toxicity on in vitro methods: one using a human cell system and the other using a rodent cell system (see website address: http:/ / iccvam.niehs.nih.gov/methods/acutetox/acutetox. htm). BALB/C 3T3 murine embryo fibroblasts and L-02 human normal liver cells were used. These cell lines have been well characterized for their relevance for toxicity studies $^{[25,26]}$. Our data clearly suggest that although $10 \mathrm{~b}$ seemed to reduce MTS/PMS reduction in a dose dependent manner, $\mathrm{IC}_{50}$ value for these cells was much higher than $\mathrm{MIC}_{50}$ value for $C$ albicans $(\sim 0.5 \mu \mathrm{g} / \mathrm{mL})$. This indicates that the formulation is preliminarily safe and warrants further study for possible human applications.

The present study indicates that tetralin derivatives are potentially applicable to the field of Psychiatry, of which the most effective are dialkylated tetralin derivatives ${ }^{[27]}$. Aminotetralins, including 8-hydroxy-2-(di-n-propylamino) tetralin
(8-OH-DPAT) and 7-hydroxy-2-(di-n-propylamino) tetralin (7-OH-DPAT) behave as preferential agonists at serotonin (5-HT)1A and dopamine D3 and D2 receptors ${ }^{[28]}$. The former affects intracranial self-stimulation (ICSS) and the latter possesses anxiolytic properties. However, there are few reports from other laboratories describing the antifungal activities of 2-aminotetralin derivatives. In conclusion, our findings suggest that 2-aminotetralin compounds deserve further study by virtue of their novel chemistry structures, definite antifungal activities and a distinctive mode of action.

\section{Acknowledgments}

Project was supported by the National Natural Science Foundation of China (№ 30672626 and 30572257).

We thank Dr Joseph HEITMAN for kindly providing the isolate $C$ albicans strain BWP17 and NJ52-1 and Dr William A FONZI for kindly offering the isolate $C$ albicans SC5314 in this study.

\section{Author contribution}

Yuan-ying JIANG, Yong-bing CAO, and Kai-hua FAN designed the research protocol; Rong-mei LIANG performed the research and wrote the paper; You-jun ZHOU and Hui TANG synthesized 10b; Ping-hui GAO,Hong-tao LIU, Yi XU, Bao-di DAI, Yong-hong TAN, and Shi-hua WANG made a critical reading of the manuscript.

\section{References}

1 Lemke A, Kiderlen AF, Kayser O. Amphotericin B. Appl Microbiol Biotechnol 2005; 68: 151-62. 
2 Ostrosky-Zeichner L, Marr KA, Rex JH, Cohen SH. Amphotericin B: Time for a new "gold standard". Clin Infect Dis 2003; 37: 415-25.

3 Perea S, Lopez-Ribot JL, Wickes BL, Kirkpatrick WR, Dib OP, Bachmann SP, et al. Molecular mechanisms of fluconazole resistance in Candida dubliniensis isolates from human immunodeficiency virusinfected patients with oropharyngeal candidiasis. Antimicrob Agents Chemother 2002; 46: 1695-703.

4 Ruhnke M, Schmidt-Westhausen A, Morschhauser J. Development of simultaneous resistance to fluconazole in Candida albicans and Candida dubliniensis in a patient with AIDS. J Antimicrob Chemother 2000; 46: 291-5.

5 Walsh TJ, Viviani MA, Arathoon E, Chiou C, Ghannoum M, Groll AH, et al. New targets and delivery systems for antifungal therapy. Med Mycol 2000; 38: 335-47.

6 Akins RA. An update on antifungal targets and mechanisms of resistance in Candida albicans. Med Mycol 2005; 42: 285-318.

7 Baloch RI, Mercer El. Inhibition of sterol 8-7 isomerase and14reductase by fenpropimorph, tridemorph, and fenpropidin in cell-free enzyme systems from Saccharomyces cerevisiae. Phytochemistry 1987; 26: 663-8.

8 Stock I. Antimycotic therapy of Tinea pedis and other foot mycoses. Med Monatsschr Pharm 2008; 31: 247-56.

9 Oku y, Takahashi N, Yokoyama K. Fungicidal activity of liranaftate against dermatophytes. Nippon Ishinkin Gakkai Zasshi 2009; 50: 9-13.

10 Schaller M, Borelli C, Berger U, Walker B, Schmidt S, Weindl G, et al. Susceptibility testing of amorolfine, bifonazole and ciclopiroxolamine against Trichophyton rubrum in an in vitro model of dermatophyte nail infection. Med Mycol 2009; 16: 1-6.

11 Yao B, Ji HT, Cao YB, Zhou Y, Zhu J, Lü J, et al. Synthesis and antifungal activities of novel 2-aminotetralin derivatives. J Med Chem 2007; 50: 5293-300.

12 Jia N, Arthington-Skaggs B, Lee W, Pierson CA, Lees ND, Eckstein $\mathrm{J}$, et al. Candida albicans sterol C-14 reductase, encoded by the ERG24 gene, as a potential antifungal target site. Antimicrob Agent Chemothe 2002; 46: 947-57.

13 National Committee for Clinical Laboratory Standards. Reference method for broth dilution antifungal susceptibility testing of yeasts. Approved standard M27-A2. Wayne, Pa; 2002.

14 Arthington-Skaggs BA, David WW, Christine JM. Quantitation of Candida albicans ergosterol content improves the correlation between in vitro antifungal susceptibility test results and in vivo outcome after fluconazole treatment in a murine model of invasive Candidiasis. Antimicrob Agent Chemother 2000; 44: 2081-93.

15 Sheng C, Zhu J, Zhang W, Zhang M, Ji H, Song Y, et al. 3D-QSAR and molecular docking studies on benzothiazole derivative as Candida albicans N-myristoyltransferase inhibitors. Eur J Med Chem 2007; 42: 477-86.
16 Sheng C, Zhang W, Ji H, Zhang M, Song Y, Xu H, et al. Structurebased optimization of azole antifungal agents by CoMFA, CoMSIA, and molecular docking. J Med Chem 2006; 49: 2512-25.

$17 \mathrm{Ji} \mathrm{H}$, Zhang WN, Zhang M, Kudo M, Aoyama Y, Yoshida Y, et al. Structure-based de novo design, synthesis, and biological evaluation of non-azole inhibitors specific for lanosterol 14r-demethylase of fungi. J Med Chem 2003; 46: 474-85.

18 Zhu J, Lu J, Zhou Y, Li Y, Cheng J, Zheng C. Design, synthesis, and antifungal activities in vitro of novel tetrahydroisoquinoline compounds based on the structure of lanosterol 14alpha-demethylase (CYP51) of fungi. Bioorg Med Chem Lett 2006; 16: 5285-9.

19 Jin H, McCaffery JM, Grote E. Ergosterol promotes pheromone signaling and plasma membrane fusion in mating yeast. J Cell Biol 2008; 180: 813-26.

20 Miao L, Nielsen M, Thewalt J, Ipsen JH, Bloom M, Zuckermann MJ, et al. From lanosterol to cholesterol: structural evolution and differential effects on lipid bilayers. J Biophys 2002; 82: 1429-44.

21 Shrivastava S, Chattopadhyay A. Influence of cholesterol and ergosterol on membrane dynamics using different fluorescent reporter probes. Biochem Biophys Res Commun 2007; 356: 705-710.

22 De Backer MD, Ilyina T, Ma XJ, Vandoninck S, Luyten WH, Vanden Bossche $\mathrm{H}$, et al. Genomic profiling of the response of Candida albicans to itraconazole treatment using a DNA microarray. Antimicrob Agents Chemother 2001; 45: 1660-70.

23 Yu L, Zhang WL, Wang LL, Yang J, Liu T, Peng JP, et al. Transcriptional profiles of the response to ketoconazole and amphotericin B in Trichophyton rubrum. Antimicrob Agents Chemother 2007; 51: 14453.

24 Dixon G, Scanlon D, Cooper S, Broad P. A reporter gene assay for fungal sterol biosynthesis inhibitors. J Steroid Biochem Mol Biol 1997; 62: 165-7.

25 Smith CN, Alexander BR. The relative cytotoxicity of personal care preservative systems in Balb/C 3T3 clone A31 embryonic mouse cells and the effect of selected preservative systems upon the toxicity of a standard rinse-off formulation. Toxicology in Vitro 2005; 19: 963-9

26 Qu XJ, Xia X, Wang YS, Song MJ, Liu LL, Xie YY, et al. Protective effects of Salvia plebeia compound homoplantaginin on hepatocyte injury. Food Chem Toxicol 2009; 47: 1710-5.

27 Bradbury AJ, Costall B, Naylor RJ. Inhibition and facilitation of motor responding of the mouse by actions of dopamine agonists in the forebrain. Neuropharmacology 1984; 23: 1025-31.

28 Lejeune F, Newman-Tancredi A, Audinot V, Millan MJ. Interactions of (+)- and (-)-8- and 7-hydroxy-2-(Di-n-propylamino) tetralin at human (h)D3, hD2, and hserotonin $1 \mathrm{~A}$ receptors and their modulation of the activity of serotoninergic and dopaminergic neurones in rats. J Pharmacol Exp Ther 1997; 280: 1241-9. 